\title{
Pemerintah sebagai Mediator Penyelesaian Konflik Sosial dan Ekonomi di Desa Karang Asem Kecamatan Sayung Kabupaten Demak (Revised; 7 September 2017)
}

\author{
Iswinarno Setia Aji \\ Prodi Ilmu Politik Universitas Negeri Semarang
}

\begin{abstract}
Abstrak
Birokrasi dibentuk sebagai wujud kompromi tertinggi yang mungkin diberikan suatu masyarakat dengan medelegasikan sebagian wewenang, otoritas dan sumberdayanya kepada sekelompok profesional tertentu. Logika yang mendasari adalah logika Principal Agent, suatu pola interaksi kontraktual ketika para masyarakat yang memiliki sumberdaya dan otoritas mempercayakan pemenuhan kepada birokrasi tertentu (Lane, 1995). Maka dengan sendirinya birokrasi sebagai sarana masyarakat dalam memperjuangkan sebuah kepentingan yang sangat beragam, dan bergerak dari waktu kewaktu akan semakin kompleks.
\end{abstract}

Kata Kunci: Konflik, Mediator, Desa, Demak

\section{Latar Belakang}

Birokrasi dibentuk sebagai wujud kompromi tertinggi yang mungkin diberikan suatu masyarakat dengan medelegasikan sebagian wewenang, otoritas dan sumberdayanya kepada sekelompok profesional tertentu. Logika yang mendasari adalah logika Principal Agent, suatu pola interaksi kontraktual ketika para masyarakat yang memiliki sumberdaya dan otoritas mempercayakan pemenuhan kepada birokrasi tertentu (Lane, 1995). Maka dengan sendirinya birokrasi sebagai sarana masyarakat dalam memperjuangkan sebuah kepentingan yang sangat beragam, dan bergerak dari waktu kewaktu akan semakin kompleks.

Birokrasi juga dapat dipahami sebagai sebuah kreasi impersonal dan simbol reifikatif yang mampu mengagregasikan berbagai kepentingan dalam konteks tertentu serta menjadi media penengah Konflik. Konstantasi ini bergerak lebih jauh dengan menjadikan birokrasi sebagai intergarator yang akan mengakomodasi berbagai aspirasi dan memperjuangkannya dalam proses Politik. Outputnya yakni sebuah Kebijakan Publik, yang dengan sendirinya harus mereflesikan konfigurasi kepentingan-kepentingan yang ada. Sebaliknya, sebuah krisis legitimasi akan terciptanya kebijakan-kebijakan yang dibuat tidak mampu mengakomodasi kepentingan masyarakat.

Setiap manusia tentu pernah mengalami konflik, baik itu berat maupun ringan. Masingmasing dari kita memiliki gaya tersendiri dalam menghadapi konflik. Pertentangan (konflik) didalam masyarakat mungkin dapat menjadikan sebab terjadinya perubahan sosial dan kebudayaan dalam masyarakat. Konflik merupakan kondisi terjadinya ketidak cocokkan antar nilai atau tujuan-tujuan yang hendak dicapai, baik yang ada dalam diri individu maupun dalam hubungannya dengan orang lain.

Pertentangan-pertentangan mungkin terjadi antara individu dengan kelompok atau perantara kelompok dengan kelompok. Pada umumnya masyarakat Indonesia bersifat kolektif. Segala kegiatan masyarakat didasarkan pada kepentingan individu, golongan, maupun kelompok di dalam masyarakat. Kepentingan individu seperti ini walaupun diakui, tetapi mempunyai fungsi sosial maupun masalah sosial yang baru di dalam masyarakat. Tidak jarang timbul pertentangan antara kepentingan individu dengan kepentingan kelompoknya, yang dalam hal-hal tertentu dapat menimbulkan perubahan-perubahan sosial. 


\section{Conflict Management Unnes Student \\ Working Paper Series 2017}

Masyarakat adalah makhuluk sosial yang selalu berinteraksi. Dalam interaksinya, manusia sering kali dihadapkan pada situasi yang disebut integrasi dan konflik sosial. Munculnya integrasi dan konflik sosial tidak terjadi dengan sendirinya dan tidak sesederhana yang kita bayangkan. Banyak faktor yang harus dikaji mengapa integrasi dan konflik sosial tersebut muncul kepermukaan. Pada umumnya integrasi dan konflik merupakan suatu gejala sosial yang sering muncul dalam kehidupan masyarakat. Bila kita menengok kebelakang, dalam sejarah, negeri ini menjadi negara yang merdeka dan berdaulat sering kali diwarnai dengan berbagai konflik, baik konflik yang terjadi antara bangsa Indonesia dan para penjajah maupun konflik yang terjadi diantara sesama bangsa ini.

Salah satu konflik yang sering berkembang di dalam masyarakat adalah konflik sosial ekonomi. konflik tersebut sangat mudah sekali tersulut jika individu atau kelompok memiliki sebuah kepentingan tersendiri untuk menguasai sumberdaya-sumberdaya tertentu. Misalnya saja sengketa tanah ataupun lahan, kepemilikan hak aset tanah tersebut sangatlah riskan timbul konflik di dalam masyarakat. Banyak individu atau kelompok yang mengklaim kepemilikan tanah ataupun sebagai ahli waris tersebut. dalam hal ini pemerintah sebagai salah satu pihak yang mengawasi dan penyelenggara landrefrom, mengancu pada pasal 7 UU nomer 5 Tahun 1960, tentang Peraturan Dasar Pokok-Pokok Agraria (UUPA) melarang pemilikan dan penguasaan tanah yang melampui batas. Ketentuan ini bertujuan untuk mencegah dan mengakhiri groot-grondbezt, yaitu bertumpuknya tanah di lahan tangan golongan-golongan dan orang-orang tertentu.

\section{Rumusan Masalah}

Rumusan Masalah yang dapat ditarik dari sebuah Latar Belakang yang ada adalah:

1. Kerangka Teori apa yang pantas untuk Sebuah Konflik Ekonomi Yang ada di Desa Karang Asem?

1. Bagaimana Peristiwa Konflik Sengketa Tanah di Desa Karang Asem bisa terjadi?

2. Siapa tokoh yang berperan dalam Konflik tersebut?

3. Resolusi apa yang digunakan Pemerintah untuk penyelesaian konflik Ekonomi diDesa Karang Asem?

\section{Tujuan}

Tujuan utama dari pembuatan makalah ini tidak lain adalah untuk memenuhi tugas mata kuliah manajemen konflik. Terlepas dari hail itu ada tujuan yang paling utama dari memenuhi tugas kuliah tersebut yaitu untuk mengetahui apakah di dalam masyarakat Indonesia yang plural ini, dan Bagaimana kehidupan bermasyarakat Indonesia itu selalu dinamis tidak mengalami konflik sama sekali.

Selain itu ada tujuan utama dari sebuah pembahasan makalah ini dalam topik yang diangkat adalah:

1. Untuk mengetahui kerangka teori apa yang pantas untuk konflik di Desa karang Asem.

2. Pembaca dapat memahami Jenis Konflik yang terjadi di Desa Karang Asem.

3. Pembaca dapat mengetahui tokoh yang berperan dalam konflik tersebut.

Pembaca dapat memahami solusi atau gambaran cara penyelesaian konflik di Desa karang Asem, apakah peran kebijakan dari pemerintah sangat diperlukan Untuk menyelesaikan Konflik yang ada.

\section{Kerangka Teori}

Konflik merupakan kondisi ketidaksesuaian diantara tujuan-tujuan dari dua pihak atau lebih yang bisa memunculkan terjadinya sengketa (dispute). Makna sebuah konflik tersendiri 


\section{Conflict Management Unnes Student \\ Working Paper Series 2017}

adalah ketidak sesuaian yang terjadi diantara dua belah pihak atau lebih (Suharko, 2016). Tulisan ini memaparkan sebuah konflik sengketa tanah balai desa karang asem, pihak yang berkonflik adalah warga atau masyarakat karang asem lebih tepatnya ahli waris Mukti dulatif yang dulunya sebagai pemilik tanah dengan Pemeritah desa Karangasem.

Ahli waris menurut hukum perdata adalah pihak atau kelompok yang menerima sebuah hak waris yang berupa harta dari pewaris yang sudah meninggal dunia. Harfiah secara islam tersendiri hampir sama dengan definisi hukum perdata, ahli waris menurut islam sendiri adalah orang-orang yang karena sebab (keturunan, perkawinan/perbudakan) berhak mendapat bagian dari harta pusaka yang meninggal dunia.

Pemerintah Desa (pemdes) merupakan penyelenggaraan urusan pemerintahan oleh Pemerintah Desa dan Badan Permusyawaratan Desa dalam mengatur dan mengurus kepentingan masyarakat setempat berdasarkan asal-usul dan adat istiadat setempat yang diakui dan dihormati dalam sistem Pemerintahan Negara

Cara untuk memahami ataupun mengetahui kecenderungan dan pola dari sebuah konflik perlu sebuah pemetaan konflik (conflict mapping). Dari sebuah pemetaan konflik (conflict mapping) tersebut dapat didapatkan sebuah basis untuk menyusun sebuah strategi pengelolaan dan penyelesaian konflik. Dari situlah sebuah konflik dapat diselesaikan dengan cara resolusi konflik yang berbentuk sementara, atau juga sebuah transformasi konflik. Wehr (1979) menawarkan pemetaan konflik yang mencakup sejumlah aspek penting.

Pertama, pemaparan tentang sejarah konflik yang mencakup mengenai asal-usul dan peristiwa-peristiwa penting dalam evolusi konflik. Kedua, konteks konflik yang melatari terjadinya konflik, yang dimaksud dengan konflik yang melatar terjadinya konflik, antara lain mencakup konteks geografis dan fisik, ekonomi dan politik. Ketiga, pihak yang berkonflik baik yang terlibat secara langsung dalam konflik maupun secara tidak langsung atau memiliki kontribusi di dalam dinamika konflik. Pihak yang berkonflik terbagi antara pihak utama dan pendukung (primary and secondary parties). Keempat, isu konflik yakni titik ketidak sesuaian yang harusdiselesaikan. Isu konflik dapat diidentif kasi dan dikelompokkan sesuai dengan faktor utama yang menimbulkan konflik, yakni berbasis fakta (facts-based), nilai (valuesbased), kepentingan (interests-based) dan di luar ketiganya, aspek non-realistik (nonrealistic). Aspek berikutnya, kelima adalah dinamika konflik. Aspek ini berkaitan dengan proses perjalanan dan evolusi konflik yang mencakup peristiwa yang mengawali, akselerasi menuju puncak konflik, dan proses peredaan konflik. Dari pemaparan aspek-aspek di atas yang telah disebutkan tadi, mendasari sebagian besar aspek keenam, yaitu jalan alternatif untuk sebuah solusi masalah dan potensi pengaturan konflik. Dalam kaitan ini ditemukan bentuk-bentuk upaya yang pernah dilakukan untuk menyelesaikan masalah, dan potensi untuk pengaturan konflik.

Mendasarkan dari pemetaan konflik yang dicetuskan maka Selanjutnya, makalah ini memberikan penekanan pada tiga aspek; yakni konteks, dinamika, dan resolusi konflik. Konteks (politik) konflik mengalami perubahan karena terjadi pergantian hak milik tanah tersebut. Proses sengketa hak kepemilkan tanah yang terus berjalan dan perubahan konteks politik tersebut berimplikasi pada dinamika konfik dan resolusi konflik.

Terdapat dua pendekatan terkait dengan resolusi konflik, yakni litigasi melalui lembaga peradilan dan penyelesaian sengketa alternatif (alternative dispute resolution-ADR) seperti mediasi, negosiasi, intervensi dari pihak yang lebih tinggi, peran pihak ketiga yang netral, dan bentuk-bentuk penyelesaian konflik lainnya. Keduanya memiliki keterbatasan dan kelebihan masing-masing. Pendekatan litigasi menghasilkan suatu kepastian, dalam bentuk keputusan pengadilan. 


\section{Conflict Management Unnes Student \\ Working Paper Series 2017}

Namun, proses litigasi berlangsung dalam situasi yang formal di pengadilan, sehingga masing-masing pihak terbawa dalam atmosfer yang kompetitif untuk memaksimalkan apa yang bisa dimenangkan. Proses litigasi juga cenderung tidak efektif dari aspek waktu dan biaya. Proses persidangan bisa berjalan lama karena adanya berbagai prosedur dan mekanisme hukum yang kompleks. Hal ini kadang ditambah lagi dengan "permainan" antar aparat penegak hukum yang menjadikan keputusan pengadilan tidak memiliki legitimasi yang kuat bagi semua pihak. Sementara itu, ADR berlangsung dalam situasi yang lebih informal. Para pihak yang berkonflik dan juga mediator bisa mengembangkan suasana kooperatif untuk memperoleh kesepakatan bersama dan mengikat kedua pihak. Namun demikian, para pihak menghadapi masalah ketika tidak ada kondisi yang memaksa mereka untuk bertemu sebagaimana terjadi pada proses pengadilan. Masing-masing pihak seringkali tidak memiliki posisi tawar yang seimbang, sehingga menyulitkan dalam proses negosiasi dan memperoleh kesepakatan yang memuaskan kedua pihak.

Data yang digunakan untuk memetakan konflik ini adalah data sekunder, yakni informasi dan peristiwa yang ditulis dan dilaporkan oleh berbagai pihak dan narasumber melalui media massa, baik yang bersifat on-line maupun off line (cetak). Pemberitaan dan laporan terkait dengan pernyataan, pendapat, dan ungkapan dari para pihak yang berkonfl ik, serta aktivitas yang melibatkan para pihak yang berkonflik secara relatif intens dimuat di media massa cetak dan online, baik media lokal maupun nasional. Seiring dengan perkembangan teknologi informasi, pernyataan, ungkapan, aktivitas dan peristiwa konfl ik ini juga direkam dan didokumentasikan melalui film, dan selanjutnya diunggah di Youtube dan situssitus tertentu yang dimiliki suatu organisasi dan perorangan.

Pengelolaan konflik pada dasarnya adalah setiap upaya intervensi (untuk mencegah aktualisasi, mendeeskalasi, menghentikan dan menyelesaikan konflik) dalam salah satu (atau lebih) tahap konflik. Konflik memiliki tahap-tahap yang berjalan secara siklikal: bermula dari sumbernya, kemunculannya, pemicu awalnya, ekselasi dan deeskalasinya, terminasinya, hingga ke hasil dan konsekuensinya, kemudian berawal lagi sebagai sumber konflik yang baru.

Sumber konflik adalah kondisi-kondisi laten dan aktual yang memproduksi keyakinan atau kepercayaan tentang adanya tujuan-tujuan yang tak selaras (Riza, 2005). Konflik ini berasal dari konstruk teoritik atau asumsi dasar tentang sifat manusia dan proses sosial yang mempengaruhinya. Secara intraksional hubunan individu dengan individu lainyya dapat mengarah pada proses-proses sosial yang disdintegrated.

Pengelolaan konflik praktiknya mengembangkan teknik-teknik seperti negoisasi, fsilitasi, mediasi, pencarian fakta, arbitase tak mengikat, arbitase mengikat, maupun adjudication (peradilan legal). Dalam pengelolaan atau resolusi konflik, teknik-teknik itu dapat dibedakan atau di kategorisasikan menurut aspek formalitas-informalitas proses-proses penyelesaian konflik.

\section{Peristiwa Konflik}

Konflik ini berawal dari Sejumlah warga yang tergabung dalam ahli waris Mukti Dulatif, yang melakukan protes terhadap Pemerintahan Desa (Pemdes) Karangasem, Kecamatan Sayung. Protes ini dipicu oleh adanya tumpukan pasir yang diduga akan digunakan untuk memasang keramik lantai gedung Balai Desa Karangasem.

Padahal, versi ahli waris, hingga kini tanah yang ditempati bangunan balai desa tersebut masih dalam status sengketa. Sedianya, ahli waris Mukti Dulatif tersebut hendak menyegel Kantor Balai Desa Karangasem tersebut. Namun, hal itu diurungkan setelah persoalan terkait dimediasi Kapolsek Sayung AKP Budi Rahmadi dan Kasatintel Polres Demak. 


\section{Conflict Management Unnes Student \\ Working Paper Series 2017}

Bahkan, sebelumnya mereka telah mengusung spanduk dengan tulisan dilarang mendirikan bangunan berbentuk apapun di atas tanah milik Mukti Dulatif. Kepemilikan tanah itu ditandai dengan sertifikat tanah persil C. Masing-masing nomor 194 persil 22 kelas 2, 0.050 dan persil C 568 persil 23 kelas 2, 0.290. Spanduk dalam bentuk MMT itu gagal dipasang dan akhirnya hanya digelar pertemuan untuk mencari titik temu kedua belah pihak. Yaitu, antara ahli waris Mukti Dulatif dengan Kades Karangasem Joko Legowo.

Pihak ahli waris juga meminta pihak Pemdes tidak mudah membikin pernyataan yang menyudutkan keluarga ahli waris Mukti Dulatif. Rifai pihak yang mendampingi ahli waris

menyampaikan bahwa pemasangan spanduk sebelumnya akan dilakukan sebagai bentuk penegasan bahwa tanah balai desa masih dalam proses sengketa. Jadi, tidak ada niatan untuk menghambat pelayanan umum atau belajar mengajar di sekolah yang ada di sebelah balai desa.

Untuk menyelesaikan sengketa antara ahli waris Mukti Dulatif dengan Pemerintah

Desa (pemdes) sebelumnya telah dilakukan secara kooperatif. Namun, dalam perkembanannya dan pelaksanaanya pemerintah Desa (pemdes) cenderung tidak mau tahu untuk menyelesaikan masalah tersebut. Ada salah satu warga yang merupakan ahli waris tanah tersebut, metuturkan bahwa Pemerintah Desa (Pemdes) tiba-tiba mendatangkan material. Karena itu, saya dan teman-teman minta balai desa jangan dibangun dulu hingga ada kejelasan masalah ini dari Pemkab Demak. Karena hal tersebutlah yang membuat beberapa warga Kelurahan Karangasem berkonflik dengan Pemerintah Desa.

Kades Karangasem, Joko Legowo saat menjelaskan kepada warga mengtakan, adanya tumpukan pasir di depan balai desa hanya akan dipakai untuk memperbaiki keramik lantai yang sudah rusak dan dibongkar. Kami hanya mau rehab atau pasang keramik lantai dan teralis saja.

Terkait dengan persoalan sengketa tanah balai desa itu, sebagai kades, Joko Legowo menunggu proses penyelesaikan di tingkat kabupaten. "Kami menunggu saja," ujar dia.

Kapolsek Sayung AKP Budi Rahmadi mengatakan bahwa agar situasi tetap kondusif, kedua belah pihak antara ahli waris dan Pemdes Karangasem agar tidak melakukan aktivitas yang sifatnya memperkeruh keadaan. "Yang ahli waris jangan menyegel balai desa. Begitupula, pihak pemerintahan desa juga untuk sementara tidak membangun balai desa. Tunggu saja bagaimana proses penyelesaian di Pemkab Demak," katanya.

Untuk menerbitkan sertifikat tanah tersebut, perlu dilakukan pengukuran ulang. Pengukuran disaksikan sejumlah pihak, antara lain Plt Sekretaris Desa Karangasem, Mufid, Camat Sayung, Sugianto, Kapolsek Sayung, Budi Rahmadi, perwakilan dari Koramil Sayung, pihak keluarga Dul Latif dan lainnya. Mufid mengaku status tanah tersebut masih dalam sengketa.

Ahli waris Dul Latif, mengajukan permintaan agar tanah yang letaknya sebagai halaman balai desa dan terdapat bangunan Pamsimas dikembalikan kepada mereka. Pada catatan pertanahan di desa, lanjut dia, tanah tersebut memang terdata atas nama Dul Latif. "Saya tidak tahu kronologisnya. Hanya, dulu Dul Latif pernah menjabat kepala desa di sini," (Suara Merdeka, 2017)

Beberapa waktu yang lalu, sengketa lahan ini sempat memanas lantaran kedua belah pihak, baik keluarga Dul Latif maupun Pemerintah Desa Karangasem, sama-sama mengklaim sebagai pemilik tanah seluas 500 meter persegi tersebut.

Sementara itu, Ketua Lembaga Studi Kebijakan Publik (LSKP) Demak, Muhammad Rifai selaku pendamping keluarga Dul Latif mengatakan, ada tiga titik tanah yang menjadi sengketa. Di antaranya tanah di depan Balai Desa Karangasem, kemudian tanah tanah seluas 2.850 meter persegi yang kini ditempati SD Karangasem, serta tanah ganti umbul seluas 1.940 meter persegi. Camat Sayung, Sugianto yang melihat pengukuran ulang tersebut menyampaikan, pihaknya perlu memantau kegiatan itu, karena menyangkut persoalan yang 


\section{Conflict Management Unnes Student \\ Working Paper Series 2017}

dihadapi pemerintah desa. Disini Rifai hanya memantau, karena ini bukan kewenangan dari Lembaga Studi Kebijkakan Publik.

\section{Pihak-Pihak yang berkonflik}

Dalam perjalanannya konflik sengketa sebagia lahan balai desa karang asem dan sekolah SD 1 kareng asem, antara pemerintah desa (Pemdes) dengan ahli waris Mukti Dulatif. Ahli waris Mukti Dulatif Mendapatkan dukungan dan dampingan dari ketua Lembaga Studi Kebijakan Publik (LKSP) Jateng, yaitu Muhammad Rifai. Sejak awal terjadinya konflik Muhammad Rifai mendampingi proses penyelesaian sengketa tanah tersebut mendatangi kantor DPRD Demak.

Datang bersama Sumari dan Yusuf Mukti selaku ahli waris mukti Dulatif, Muhammad Rifai datng ke Gedung DPRD Kabupaten Demak untuk bertemu dengan Anggota Dewan. Ternyata niat mereka terwujud ketiga bertemu dengan Ketua Komisi A DPRD Kabupaten Demak yaitu Sunari. Kepada politisi Golkar itu, mereka meminta gani rugi tanah yang selama 4 tahun lalu menjadi Bangunan Sekolah dan sebagian Bangunan kantor kepala Desa Karangg Asem. Tuntutan mereka kepada Pemerintah Cuma Satu yaitu meminta Ganti rugi kepada pemerintah.

Dulunnya tanah tersebut adalah milik orang tua Sumari dan Yusuf Mukti, yaitu Mukti Dulatif. Semasanya Mukti Dulatif adalah Seorang kepala Desa di karang asem, beliau pensiun atu berhenti menjabat sebagai kepala desa di tahun 1975 setelah dua tahun kemudian di tahun 1977 tanah C194 / persil 50 / DII / 0,50 seluas 1000 meter persegi itu di pinjamkan kepada pemerintah desa untuk didirikan kantor desa sementar (Tribun Jateng, 2016). Namun pada tahun 2010 pemerintah Desa karang asem memutuskan sepihak untuk menghibahakan tanah milik almarhum Mukti Dulatif untuk ditempati SD dan kantor Desa tanpa persetujuan pihak keluarga (Suara Merdeka, 2016).

Hal itulah yang menyebabkan munculnya gejolak konflik antara ahli waris Dulatif dengan pemerintah Desa. Sementara itu menurut Pemerintah Desa Karang Asem, melalui Kepala desa Karang Asem Joko Legowo, ditahun 2010 tanah ini sudah sepenuhnya hak milik pemerintah desa, memalui hibah.

\section{Resolusi Konflik dalam Kebijakan Publik}

Dalam realitas, masyarakat modern tidak hanya bisa dilihat dari presepektif strukturalfungsional dan teori konsensus yang menekankan pada integrasi, tetapi juga harus dipandang dari sisi lain, yaitu muncul dan berkembang diferensiasi yang melahirkan sebuah konflik di dalam masyarakat. Perkembangan masyarakat yang tidak selalu menyatu (integrasi), tetapi juga serinng memecah atau memisah menjadikan teori konflik relevan dalam menganalisis perkembangan masyarakat kotemporer.

Dalam kasus konflik di Desa Karangasem, kecamatn sayung. Kabupaten Demak. dapat dikatakan konflik yang terjadi antar kelompok masyarakat dengan Pemerintah Desa. kelompok masyarakat yang bertikai adalah kelompok masyarakat yang mengeklaim dirinya sebagai kelmpok ahli waris Mukti Dulatif, dengan Pemerintah Desa Karangasem. Konflik ini terjadi karena sejumlah kelompok masyarakat mengeklaim bahwa tanah yang dbuat untuk menjadi balai desa Karangasem adalah tanah warisan orang tuanya ataupun leluhurnya. Sedangkan dari kelompok pemerintah desa mengklaim bahwa tanah yang akan dibuat untuk balai desa karang asem merupakan tanah pemerintah kabupaten (pemkab) Demak,yang dihibahkan kepada Pmerintas Desa Karangasem untuk dibangun Balai desa.

Menurut Hendrick Ada 5 cara yang bisa digunakan untuk menyelesaikan konflik. Yaitu

a. Gaya penyelesaian konflik dengan mempersatukan (integrating) 


\section{Conflict Management Unnes Student \\ Working Paper Series 2017}
b. Gaya penyelesaian konflik dengan kerelaan untuk membantu (obliging)
c. Gaya penyelesaian konflik dengan mendominasi (dominating)
d. Gaya penyelesaian konflik dengan menghindar (avoiding)
e. Gaya penyelesaian Konflik dengan Kompromis (compromissing).

Konflik antara ahli waris Mukti Dulatif dengan Pemerintah desa (Pemdes) Karangasem, kecamatan Sayung, Demak. Menurut saya dapat di selesaikan dengan 2 cara yang di sebutkan oleh Hendrick yaitu cara Integrating dan cara compromissing.

1. Mempersatukan Pihak yang bertikai ( integrating)

Cara ini menggunakan pertukaran informasi pada pihak yang bertikai. Pihak yang berkonflik seperti kasus diatas yaitu pihak kelompok ahli waris Mukti Dulatif, dengan pihak Pemerintah Desa Karangassem di pertemukan dan meminta pendapat kedua belah pihak, dan mempersatukan pendapat yang di keluarkan oleh kedua pihak tersebut. cara ini sering disebut juga mengakomodir permintaan kedua belah pihak yang bertikai. Biasanya cara seperti ini di gunakan oleh pihak-pihak pengamanan untuk menyelesaikan konflik sebelum berlanjut ke meja hijau. Penyelsaian konflik dengan cara mempersatukan ini mendorong tumbuhhnya pikiran kreatif, dimana mengembangkan alternatif merupakan bagian pentig dari gaya penyelesaian konflik. Dalam pengelolaan konflik di dalam Sosial Masyarakat dengan model integrating menekan kan individu dan orang lain dalam mensinergikan sebuah pendapat yang diutarakan oleh kedua belah pihak yang sedang bertikai.

Walaupun beberapa kelompok masyarakat tidak mengutamakan penyelesaian dalam menerapkan gaya ini dengan alesan, Karena adanya sentimetil yang menempatkan loyalitas kelompok lebih tinggi ketimbang kepada kekuatan politik. Tetapi jika tidak menemukan cara yang yang efektif dalam menyelesaikan konflik cara ini bisa digunakan untuk jurus pamungkas untuk penyelesaian masalah. Walaupun dalam kasus ini sudah sampai ke pemkab Demak, Tetapi belum ada keputusan Resmi dari Pemkab demak soal kasus ini.

2. Kompromi (compromissing)

Kompromi adalah salah satu bentuk akomodasi dimana pihak-pihak yang terlibat saling mengurangi tuntutannya agar tercapai suatu penyelesain terhadapa perselisiahan yang ada. Hampir sama dengan integrating, jika integrating mengamodir semua pendapat-pendapat yang diuntaran oleh peihak yang bertikai, tetapi di kompromi ini kedua belah pihak harus saling mengurangi tuntutan. Kompromi dipandang efektif sebagai cara untuk menyelesaikan konflik bila sebuah isu yang dikembangkan sangat kompleks atau bila ada keseimbangan kekuatan. Seperti halnya kasus konflik yang ada di desa karangasem kecamatan sayung, Demak. Konflik ini terjadi karena dari Sejumlah warga yang tergabung dalam ahli waris Mukti Dulatif, yang melakukan protes terhadap Pemerintahan Desa (Pemdes) Karangasem, Kecamatan Sayung.

Protes ini dipicu oleh adanya tumpukan pasir yang diduga akan digunakan untuk memasang keramik lantai gedung Balai Desa Karangasem. Padahal tanah yang dibuat untuk balai desa tersebut belum jelas kepemilikannya. Meski acap kali kedua belah pihak seperti ahli waris mukti dulatif dengan pemerintas desa sudah sering dipertemukan dan dimediasi oleh pihak ketiga seperti kapolsek sayung, tetapi belum membuahkan hasil yang pasti soal kepemilikan tanah tersebut. meskipun kasus sengketa tanah ini belum sampai ke meja hijau, pihak kepolisian pun menyerahkan kasus ini kepada pemkab Demak selaku pihak yang membuat kebijakan. 


\section{Conflict Management Unnes Student \\ Working Paper Series 2017}

Selain menggunakan Penyelesaian Konflik secara ADR (alternative dispute resolution). Sebuah konflik dapat diselesaikan melalui sebuah kebijakan yang dikeluarkan oleh Pemerintah, sebagai field of study, pendekatan ini relatif baru dan lahir sebagai wujud kepedulian terhadap merebaknya fenomena non-kooperasi, konfrontasi, konflik kepentingan yang dapat berujung pada konflik bersenjata, serta bagaimana upaya untuk mencari solusi atas konflik tersebut.

Jika ditelaah penyelesasian konflik di Desa Karang Asem juga membutuhkan sebuah peran dari pemerintah daerah Kabupaten Demak. Pertanyaannya apakah mungkin sebuah kebijakan yang dikeluarkan oleh pemerintah dapat digunakan untuk menyelesaikan sebuah Konflik. Seperti halnya Konflik sosial ekonomi yang berkasuskan dengan adanya sengketa Lahan antara ahli waris Mukti Dulatif dengan Pemerintah Desa.

Sebuah kebijakan (policy) dari pemerintah untuk menyelesaikan konflik yang ada di Desa Karang Asem. Menurut Oyamada (2002) mengajukan argumen bahwa praktik kebijakan di tingkat lokal, terutama dalam konteks masyarakat yang baru saja keluar dari situasi-situasi konfliktual yang didukung oleh masyarakat luas adalah mungkin. Jika, yng pertama diterapkan sistem kebijakan yang berbeda untuk tahap-tahap konflik yang berbeda. Tahap resolusi dan pasca konflik akan memerlukan peran dari kebijakan pemerintah. Yang kedua, jika adapengakuan bahwa yang berlaku adalah kekuatan diwilayah (complex emergencies) yang memerlukan keterlibatan masyarakaat internasional dalam urusan politik local atau domestik, penciptaan dan penjagaan perdamaian, pemerkaraan, birokrasi publik, hak asasi manusia (HAM), penanganan konflik, urusan-urusan humanier lain dan aspek rehabilitasi dan pembangunan.

Pendekatan yang seperti ini, ada sejumlah aspek atau dimensi yang diperlukan oleh pemerintah untuk menengahi situasi konflik yang ada di Desa Karang Asem. Yang pertama adalah, rekonsiliasi politik, yaitu kebutuhan untuk mendamaikan pihak-pihak yang bertikai, penempatan kembali legitimasi negara atau pemerintah setempat (Pemda) dan rekonstruksi Sosial terhadap pihak pihak yang berkonflik. Maksud dari dimensi tadi adalah pemerintah disini harus melakukan rekonsiliasi politik, rekonsiliasi politik di sini maksudnya pemerintah harus mengeluarkan sebuah PERDA (Peraturan Daerah) ataupun kebijakan-kebijakan yang lain untuk menengahi Konflik di Desa Karang Asem. Pemerintah Kabupaten Demak juga bisa menjembatani permintaan kedua belah pihak dampak konflik yang ada di Desa Karang Asem agar tidak meluas dan memberi dampak Kemana-mana.

Yang Kedua adalah Restabilitasi kehidupan sosial, yaitu keperluan untuk menata kembali lembaga-lembag publik yang esensial untuk memastikan pelayanan dasar masyarakat, jaminan keamanan dan kebebasan. Maksud dari dimensi kedua ini adalah Pemerintah Daerah Demak Melalui Pemerintah Desa Karang Asem harus transparansi dalam menyelesaikan konflik yang ada, pemeritah daerah tidak boleh berpihak kesalah satu pihak dalam memberi keputusan dan menjembatani konflik yang ada. Terlepas dari dimensi itu semua peran pemerintah daerah Kabupaten Demak sangatlah besar untuk menjembatani konflik di desa Karang Asem.

\section{Kesimpulan}

Konflik antara ahli waris Mukti Dulatif dengan Pemerintah desa sudah berlangsung sejak tahun 2016 dan belum berakhir. Geajala penggunaan kekerasan psikologi dan fisik oleh masing-masing pihak mengidentifikasikan adanya pergeseran dari proses konflik manifest ke proses konflik manifest agresif. Himbauan agar kedua pihak tidak menggunakan cara-cara yang anarkis atau dengan cara kekerasan dalam mengerjar tututannya, dan menempuh jalur pengadilan, menguatkan indikasi dari pergeseran bentuk dari proses konflik itu sendiri. Namun 


\section{Conflict Management Unnes Student \\ Working Paper Series 2017}

tidak disadari secara langsung maupun langsung konflik kedua belah itu konflik tersebut telah membuat kerugian psikologi yang ada di masyarakat sekitar yang terdampak dari konflik tersebut, seperti siswa-siswi SD 01 karang Asem.

Kedua pihak utama memiliki tujuan yang saling tidak bersesuaian. Dari aspek isu, konflik ini berbasis nilai ekonomi sekaligus kepentigan beberapa pihak. Dari dimensi nilai lain, ahli waris Mukti Dulatif meyakini bahwatanah tersebut adalah miliknya, dan mereka mempuyai dan memegang sertifikat hak kepemilikan tanah tersebut. disisi lain pihak pemerintah Desa juga mengklaim tanah ini merupakan hibah dari mantan kepala Desa karang asem yaitu almarhum mukti abdul latif, dan tanah tersebut tidak digunakan untuk kepentingan pribadi atau sekelompok orang melainkan untuk kepentingan semua masyarakat desa karang asem.

Dinamika konflik ditandai oleh peristiwa-peristiwa penting yang berimplikasi pada posisi yang konfrontatif.dari awal periode konflik sampai dengan periode akhir konflik, kedua belah pihak menegaskan dan memperjuangkan tujuannya melaui jalur pemda dan jalurr hukum yaitu melalui meja hijau.

Meskipun nantinya putusan yang mutlak dan sepenuhnya mengikat yaitu putusan dari jalur hukum yaitu jalur pengadilan, dan pemerintah daerah mengeluarkan suatu perda yng mengikat sengketa tersebut. walaupun dari keputusan tersebut salahh satu piak harus mengakui kekalahan dalam memperjuangkan lahan atau tanah tersebut. bila tidak legowosalah satu pihak dalam putusan pengadilan makan konflik tersebut akan terus terjadi, bahkan akan menimbulkan sejumlah korban, dan sejumlah tersangka jika konflik itu tidak disudahi. Seiring dengan perda (peraturan derah) yang mengikat untuk mengakhiri konflik.

Konflik seperti ini sudah menjurus ke pada penyelesaian konflik dengan gaya pemaksaan atau coercion. Maka dengan penyelesaian Konflik model Coercion, Kedua belah pihak yang berkonflik akan menerima segala macam hasilnya, walaupun ada merasa di rugikan tetapi konflik tersebut tidak akan timbul lagi untuk jangka pendek maupun jangka panjang.

Dari studi kasus konflik di Desa Karang asem Kecamatan Sayung, Kabupaten Demak. Konflik tersebut tidak akan berjalan lama jika kedua belah duduk bersama dan memahami akar pokok permasalahan yang ada. Disini peran pemerintah sangat diperlukan sebagai mediator dalam penyelesaian konflik tersebut, sebelum kasus konflik tersebut diangkat ke meja hijau atau pengadilan. Segala putusan yang akan dikeluarkan pengadilan akan menguntungkan salah satu pihak yang berkonflik dan akan merugikan salah satu pihak juga.

Bila konflik tersebut dimenangkan oleh pihak ahli waris Mukti Dulatif maka pihak Pemerintah Desa akan Rugi secara sosial dan ekonomi. bilamana tidak tanah sebesar 1000 meter tersebut sebagian sudah menjadi sekolah SD 1 Karang Asem. Bila itu terjadi maka 300 Siswa sekolah Dasar tersebut akan terjeda untuk mendapatkan pendidikaan. Sebaiknya konflik di Desa Karang Asem diselesaikan Secara kekeluargaan, Pemeran Pemda (Pemerintah Daerah) Kabupaten Demak sangat di perlukan sebagai mediator konflik di Desa Karang Asem. Jika Mana konflik tersebut di selesaikan Secara kekeluargaan maka kedua belah pihak tersebut tidak akan merasa dirugikan. Hal tersebut tidak akan berdampak kepada Masyarakat Desa Karang Asem, jika kedua belah pihak dapat menemukan solusi bersama, dan sebuah Resolusi Konflik akan terwujud di Desa Karang Asem.

\section{Daftar Pustaka}

Arfani, R. N. 'Governance' sebagai Pengelolaan Konflik. JSP (Jurnal Ilmu Sosial dan Ilmu Politik), 8(3), 309-330.

Arumsari, N., Septina, W. E., Luthfi, M., \& Rizki, N. K. A. (2017). KOMUNIKASI POLITIK KEPALA DESA DALAM MENDORONG INOVASI PEMBANGUNAN DESA: STUDI KASUS TIGA DESA DI LERENG GUNUNG UNGARAN, JAWA TENGAH. Jurnal Politik Indonesia, 2(1), 87-100.

Handoyo, E., Su'ud, A., \& Sunarjan, Y. Y. F. R. (2007). Studi Masyarakat Indonesia. Fakultas Ilmu Sosial, Universitas Negeri Semarang. 


\section{Conflict Management Unnes Student \\ Working Paper Series 2017}

Ida, (2017). Konflik Tanah Balai Desa Karang Asem Berlanjut. (Online). (https://radarsemarang.com/2017/01/07/konflik-tanah-balai-desa-karangasemberlanjut/, diakses 25 Mei 2017). , (2017). Dipersoalkan Tanah Balai Desa Karang Asem. (online). (http://berita.suaramerdeka.com/smcetak/dipersoalkan-tanah-halaman-balai-desakarangasem/, diakses 25 Mei 2017).

Ramadlan, M. F. S., \& Wahyudi, T. H. (2016). PEMBIARAN PADA POTENSI KONFLIK DAN KONTESTASI SEMU PEMILUKADA KOTA BLITAR: ANALISIS INSTITUSIONALISME PILIHAN RASIONAL. Jurnal Politik Indonesia, 1(2), 143162.

Saifuddin, A. F. (2005). Antropologi Kontemporer: Suatu Pengantar Kritis Mengenai Paradigma. Kencana: Prenada Media.

Soekanto, S., \& Soemarjan, S. (1969). Sosiologi: suatu pengantar. Jajasan Penerbit Universitas Indonesia.

Surbakti, R. (1992). Memahami ilmu politik. Grasindo.

Seftyono, C. (2012). Pembangunan Berbasis Waterfront dan Transformasi Konflik di Bantaran Sungai: Sebuah Pemikiran Awal. JSP (Jurnal Ilmu Sosial dan Ilmu Politik), 16(1), 75 83.

Suharko, S. Masyarakat Adat versus Korporasi: Konflik Sosial Rencana Pembangunan Pabrik Semen di Kabupaten Pati Jawa Tengah Periode 2013-2016. JSP (Jurnal Ilmu Sosial dan Ilmu Politik), 20(2), 97-116.

Suparman, Nanang. 2017. Evaluasi Kebijakan Pendelegasian sebagian Kewenangan Bupati kepada Camat di Kecamatan Sagala Herang Subang Tahun 2015. Politik Indonesia: Indonesian Political Science Review, 2(2), 159-178.

Wahab, Solichin Abdul. 2010. Analisis Kebijaksana: Dari formulasi Ke Implementasi Kebijaksanaan Negara. Jakarta: PT. Bumi Aksara. 